\title{
Observation on the Apical Meristem of Rice Roots*
}

\author{
by Kei-ichi Shimabuku**
}

\section{Received August 5, 1959}

Since 1957 a comprehensive survey on the root system of the rice plants has been carried on by many investigators chiefly of the agricultural field, and the writer has undertaken a part of anatomical study. Although much work on the root apical meristem of the vascular plants has been done by a considerable number of investigators and many valuable contributions have been made, our knowledge on that of the rice plant is apparently insufficient. The present investigation was commenced with the purpose to get an accurate knowledge in the behaviours of apical initials and their derivatives in the promeristem, and, thus, to offer the reliable basis for a consideration of the tissue differentiation at higher levels and, on the other hand, of the determination of an appropriate length of the root tip for the chemical analysis and other studies.

\section{Materials and Methods}

Oryza sativa L. variety Norin No. 29 which was grown in seed beds or paddyfields according to the ordinary method was used in this investigation. Seminal and adventitious roots were collected at various intervals, so as to obtain successive stages of development. Materials were killed and fixed in FAA, and dehydrated in normal butyl alcohol. Paraffin sections were usually cut at $10 \mu$, and stained with a combination of safranin and Heidenhain's iron-alum haematoxylin or fast green.

\section{Observation}

In the present study, the root is conveniently divided into following zones: 1) the initial region composed of a group of initial cells; 2) promeristem including the initial region; 3) the meristematic zone which occupies between approximately 100 and $500 \mu$ or more above the root tip***; 4) the zone of elongation; and 5) the zone of maturation. In the root tip, there are three sets of initials in many cases. One gives rise to the stele, the second to the cortex, and the third to the root cap (Fig. 1; Pl. I-A, B). In a few instances, however, the initials appear to be separated into four sets, that is, the stele, the cortex, the epidermis, and the root cap start from independent initials respectively (Figs. 2, 4; Pl. I-C).

The stelar initials always occur as a single layer of cells at the stele apex, the boundary between the stele and the cortex being sharply defined immediately behind the initials (Figs. 1, 2; Pl. I-A, B, C). In the median longitudinal section stelar initials are usually represented by two (Fig. 1), sometimes one or three cells. They are fairly variable in shape, mostly elliptical or polygonal, and they appear to divide

* Contributions from the Division of Plant Morphology, Botanical Institute, Faculty of Science, University of Tokyo, N. S. No. 83. This report was presented partly at the annual meeting of the Botanical Society of Japan, held in October 1958, at Kyushu University. Part of the cost of this investigation is paid by a grant from the Ministry of Agriculture and Forestry.

** Botanical Institute, Faculty of Science, University of Tokyo, Hongo, Tokyo, Japan.

*** In this investigation, the root tip is represented by the group of initial cells and does not mean the tip of root cap. 
in irregular directions. In the transverse section, increase in the number of stelar cells is not so remarkable in any directions at any levels, and growth of the cells, especially that of the parenchymatous cells, is also not conspicuous, but most stelar elements maintain the size of subdividing stage. Thus the stelar circumference expands but slightly and gradually. In the longitudinal sections, however, it is observable that frequent transverse cell divisions occur throughout the meristematic zone. Most of vascular elements become discernible at a level rather far from the stele apex, excepting the mother cell of the central vessel which is differentiated very early within $40 \mu$ from the root tip. The pericycle is composed of one layer of cells which are almost equal in size and shape, and is interrupted by the protoxylem elements which are located in direct contact with the endodermis (Pl. I-E).

The number of protoxylem poles varies with root size. In the seminal root usually hexarch (Pl. I-E), while in the adventitious roots it fluctuates between 5-14, mostly 10 or nearly so. A protoxylem, as seen in Pl. I-E, occurs as a radially extending group of a few cells accompanied with an early-formed metaxylem vessel situated at the inner end of the row. The metaxylem is usually distinguishable by its relatively larger size (Pl. I-E) and differentiates before the protoxylem becomes visible. In the seminal and a number of the first-formed adventitious roots, the late metaxylem is represented by a single central vessel at the centre of the stele (Pl. I-D, E), while in the large later-formed adventitious roots, there are three or four central vessels which encircle a small pith ( $\mathrm{Pl}$. I-F). The central vessel differentiates foremost among the stelar elements, the early metaxylem follows, and the protoxylem is defined latest, while the maturation of elements takes place in reverse order. The first-formed protophloem is represented by a single sieve-tube which is diamond-shaped in cross sectional outline and is located immediately inside of the pericycle (Pl. I-E). Two small square cells contiguous to the two inner faces of it seem to be companion cells. The immature sieve-tube contains deeply stainable substanes, whereas in the mature one the contents become clear (Pl. I-E). The metaphloem cells are mostly round in shape, and larger than the protophloem cells.

Between the root cap initials and the stelar initials, usually are the cortexepidermal initials which act as the common initials of the cortex and epidermis (Figs. 1, 3; Pl. I-A, B). In most cases, they are composed of two cells in the median longitudinal section (Fig. 1; Pl. I-A, B), occasionally one or three. So far as the present investigation concerned, there seems to be no correlation between the number of initial cells and the root size. The cortical subinitials and the epidermal subinitials are originated from the cortex-epidermal initials. The mode of cell division of the initials seems to be summarized as follows (Figs. 1, 3; P1. I-B): ordinarily an initia ${ }^{1}$ produces first a derivative by an anticlinal division, and soon a periclinal division of the latter appears to follow; the inner cell thus formed becomes a cortical subinitial, and the outer one, an epidermal subinitial.

As has been mentioned above, occasionally the cortex and the epidermis appear to start from the independent initial zones, namely, the cortical initials and the epidermal initials (Figs. 2, 4; Pl. I-C). In such a case, the cortical initial zone is composed of two or three cells in the median longitudinal section. The mode of cell division of both initial zones resembles that of the cortical and the epidermal subinitials in the ordinary root tip (Figs. 3, 4).

The epidermal layer appears to be completed rapidly by frequent radial divisions of its subinitials and their derivatives near the root tip. In upper parts, however, the number of epidermal cells in transverse sections increases but gradually, for instace, 
in a root it is 78,87 , and 99 at the levels 50,100 , and $200 \mu$ respectively from the root tip. Thus, their number on the circumference is almost determined in earlier stages of the ontogeny. On the other hand, as clearly shown in the longitudinal
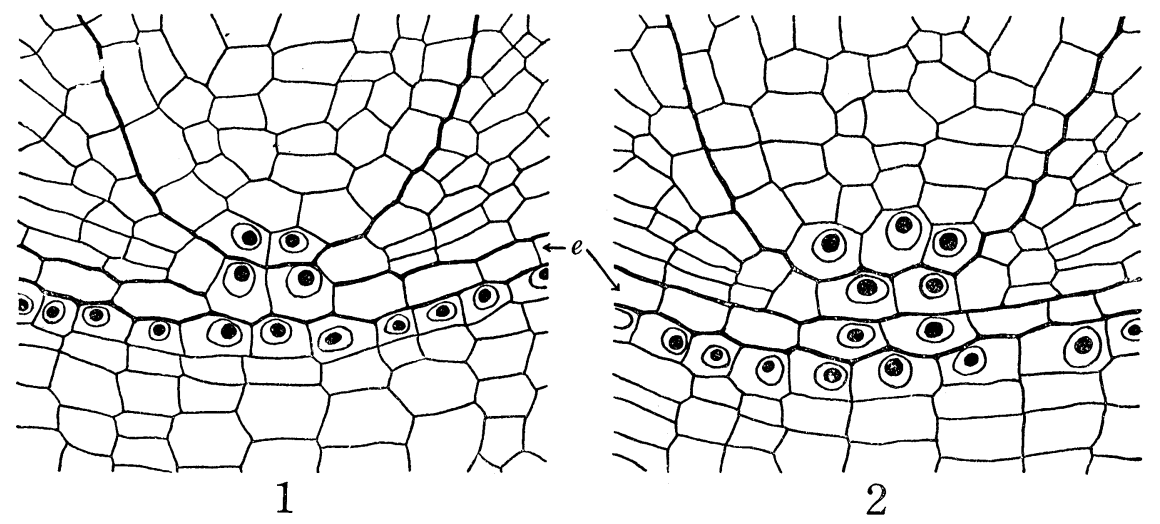

Figs. 1, 2. Median longitudinal sections through the initial region. Nuclei are shown in initial cells only, $e$ epidermis, $\times 800$. (Compare with Pl. A-C.) 1 , ordinary feature of the initial region; 2, four-layered initial zone.

section, the epidermal cells repeat frequent transverse divisions throughout the meristematic zone. The periclinal divisions, however, could not be observed at any levels, thus the epidermis apparently consists of a single layer of cells (Pl. I-A, D). Within the level approximately $100 \mu$ they suddenly increase their radial diameter, and then expand gradually in tangential direction at upper parts. In the zone of active cell division of the epidermis, the radial diameter is usually twice or three times as large as the tangential diameter (P1. I-D). Elongation of the cells begins after they rapidly attain their full radial diameter in the meristematic zone.

The cortical subinitials rapidly produce the derivatives by their anticlinal divisions as in the epidermal subinitials, and the derivatives are soon turned into the meristematic endodermis by whose periclinal divisions all cortical elements are produced (Fig. 3; P1. I-G). The following four zones are distinguishable in the cortex: 1) the outermost layer or the exodermis; 2) one or two layers of small cells which differentiate later into the sclerenchyma; 3) several layers of thin-walled cortical cells situated inside the future sclerenchyma; and 4) meristematic endodermis which is turned later into typical endodermis.

The periclinal divisions of the meristematic endodermal cells (Pl. I-G) occur mostly within $150 \mu$ from the initials, though this distance varies to some extent according to the size of roots and the stage of development. The meristematic endodermal layer always produces its derivatives centrifugally, in other words, there is no centripital division. In most of cortical cells no further periclinal division occurs excepting occasional divisions in the future sclerenchymatous layer. Th enumber of cortical layers and that of the meristematic endodermal cells on the circumference vary considerably according to the root size.

The thin-walled cortical cells seldom or never divide themselves radially, since in transverse sections these cells usually show a regular radial arrangement (PI. I-D), which, however, is sometimes disturbed by occasional radial cell divisions of the outer thin-walled cortical parenchyma and the meristematic endodermis (Pl. I-F). On the 
other hand, transverse cell divisions are frequent throughout the meristematic zone.

The exodermis is derived from the meristematic endodermis by its first periclinal division (Figs. 3, 4). In the meristematic zone and at the level where their growth begins, the exodermal cells apparently differ from the epidermal cells in shape and size (Pl. I-D), as well as in the manner of growth. In the zone of elongation of the root, the exodermal cells expand only slowly both in tangential and radial directions, thus they are almost equal in tangential and radial diameters in the zone of maturation.

Immediately beneath the exodermis there are one or in part two layers of cells which are the smallest of all the cortical cells, and contact tightly with each other (Pl. I-D, F). They turn finally into sclerenchymatous cells whose walls are thickened foremost of all the parts of the root. They arise from the meristematic endodermis after the exodermis, and enlarge slightly and gradually in all transversal directions, while they divide in radial, occasionally also in tangential direction. They maintain their squarish or polygonal outline and almost uniform throughout their developmental stages.

Most parts of cortical layers are occupied by the thin-walled parenchymatous cells arranged in regular radial rows in the transverse section (Pl. I-D). These cells are derived last from the meristematic endodermis by its periclinal divisions. They are at first very flattened rectangles in shape and later become elliptical, when diamondshaped intercellular spaces appear at their corners (P1. I-D, F). These spaces become visible in the outer layer of the thinwalled parenchyma at the level approximately $50 \mu$ or less from the root tip where the root cap still persists, and formation of the spaces proceeds centripetally. Cells of both the inner and the outer layers of the thinwalled cortical parenchyma maintain more deeply stainable contents for a long time in contrast with those of the middle layer (Pl. I-D). The cell walls of these cells are slightly thickened when the root becomes mature. These cells maintain the shape after the other thin-walled cortical cells are ruptured eventually by the formation of large air spaces.

In the median longitudinal sections observed, the root cap initials are ten or nearly so in number. Cell divisions of these initials take place periclinally, but rarely anticlinally, and further periclinal divisions of their derivatives form a central core with regular parallel rows of cells. On the other hand, at the periphery of the cap the derivatives of the initials are divided periclinally
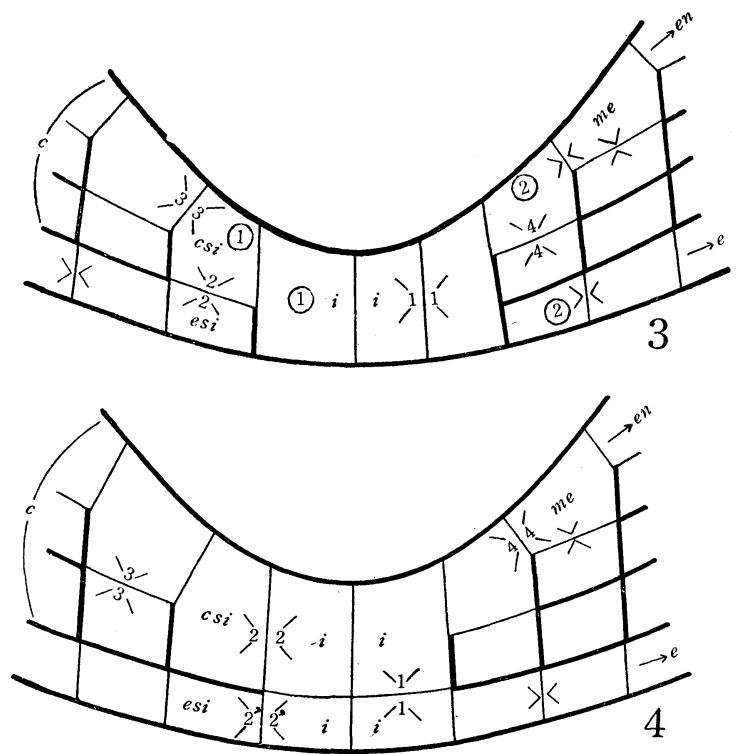

Figs. 3, 4. Diagrams of median longitudinal sections of the cortex-epidermal initials showing cell divisions. 3 , ordinary feature of the cortex-epidermal initials; 4 , separated initials by periclinal divisions: $i$ initial cell, csi cortical subinitial, esi epidermal subinitial, me meristematic endodermal cell, $c$ cortex, en endodermis, $e$ epidermis; numbers indicate the order of cell divisions. Further explanations in the text. 
as well as anticlinally, thus the arrangement of the cells in the outer periphery of the cap differs, from that of the central core.

\section{Discussion}

As has already been shown by many investigators ${ }^{1,2,3}$, initials of rice root are usually composed of three distinct layers, namely, the stelar, the cortex-epidermal, and the root cap initial layers respectively. The similar arrangement of initials was described by Heimsch ${ }^{4}$ ) in Hordeum, and by Clowes $^{5}$ ) in Triticum and Zea, and furthermore according to Schüepp ${ }^{6}$ ), there are many other monocotyledons including many grasses with similar organization. Thus the usual organization of the apical meristem in the rice root should be regarded as the type most common among the Graminae.

Clowes $^{7}$ ) has noted that in the majority of median longitudinal sections of Zea and Triticum roots, two cells occurred at the pole of the periblem-dermatogen complex; the pole of apical meristem which has been called 'quiescent centre', is composed of cells which are either nondividing or slowly dividing. His statement has been supported by Jensen and Kavaljian ${ }^{8}$ ), who noticed in the root tip of Allium cepa that no divisions were observed in the region of apical initial group.

In the rice roots, however, it was ascertained that the cortex-epidermal initials seem to maintain the ability of cell division. Usually the cortex-epidermal initials are divided at first anticlinally and then the derivatives divide periclinally to form the cortical and the epidermal subinitials. One of the reasons that the alteration in number of the polar cells may be due to the difference of the stage of cell division. After the periclinal division of the derivatives is finished, the cortex-epidermal initials appear to consist of two cells and at that stage they attain maximum size (Figs. 3, 4). Thus the cortex-epidermal initials may be fundamentally composed of a small number of cells.

In a few instance, however, the initial region appears to be separated into four layers: the stelar, the cortical, the epidermal, and the root cap initial layers. Clowes ${ }^{5}$ ) has noted that the pole of apical meristem may play a cytogenerative role when the architectural pattern is upset after wounding. According to Pellegrini ${ }^{9}$ ), the action of promeristem is conditioned by a certain minimal number of initials in his surgical experiment. Kaufman's experiment ${ }^{3}$ ) should be noticed in this connection. He has observed in rice that adventitious roots in 2, 4-D-treated shoots differ from those of control plants in the behaviour of the protoderm-cortex initials. Instead of dividing only anticlinally as in untreated root apices, these cells divide both anticlinally and periclinally and give rise to several layers at the summit of the protoderm-cortex zone, whereas in the other initials any morphological effect is not found. The fact in his observation may suggests that, in rice roots, at least the cortex-epidermal initials retain an ability of the periclinal division, and the cytogenerative role of these initials is possibly occurred under certain conditions. From the fact that in the present study the four-layered initial zone is found only among relatively large later-formed adventitious roots, it may be conceivable that the latent ability of the periclinal division is brought to light by the increase of root size. Heimsch ${ }^{4}$ ) has observed in barley roots that between the caryptorogen and the stelar initials there are the common initials of the cortex and epidermis, and they are one or two cells deep in those poles. Though he gave no explanation on the cause of the alteration of the number of initial cells, his observation suggests that the same phenomenon as in the case of rice 
plants is also present in barley, and further that the constructional types of roots in vascular plants may be changeable under certain conditions.

According to Heimsch ${ }^{4}$ ) the adventitious roots of barley seem to be characterized by several central vessels. Their number in the rice, however, varies with size of roots. In small early-formed adventitious roots, the late metaxylem is represented by a single central vessel as in the case of the seminal root.

Juliano and Aladama ${ }^{10}$ ) have observed that the pericycle in rice plants is mostly continuous, though rarely it is interrupted by the protoxylem. In the present study, however, the latter condition is always observed. According to Guttenberg ${ }^{11}$ ), the latter type of pericycle seems to be quite usual in the Graminae.

Williams ${ }^{12}$ ) has indicated that in the tip of the primary root in many vascular plants the cell layer which becomes the endodermis finally, acts like a cambium giving rise to all the tissues between the endodermis and the exodermis (he called it ' hypodermis'). The cambial nature of endodermal cells was confirmed also in this study. All the cortical cells, namely, exodermis, sclerenchyma, thin-walled cortical cells, and endodermis, are of the same origin, though they are clearly distinguishable in shape, size, manner of division and growth, as well as in final wall thickeness.

Judging from the staining reaction, shape, and number of cells of each layer of the cortex mentioned above, it seems quite apparent that the cells of outer layers of the cortex and the endodermal cells maintain for a long time an ability of the anticlinal division. Disturbance of regular radial rows of cells in the thin-walled cortical parenchyma seems to depend upon anticlinal divisions of the cells of its outer layer and the endodermal cells. It is also confirmed that most of the cortical cells maintain no ability of periclinal division excepting the future sclerenchymatous cells in which such divisions occur occasionally, and that the cells of middle portion of the thin-walled cell layer of the cortex have no ability of division in any directions. The level at which the diamond-shaped intercellular spaces appear agrees with Boeke's observation $\left.^{13}\right)$.

According to Clowes $^{5}$ ), there are two types of organization in root apices of grasses, so-called Triticum type and Zea type. He noted that the difference between the two types of organization depends chiefly upon the patterns of division within the cap, and can possibly be related to the difference in size of the apices. The general pattern of the rice root resembles Zea type.

I wish to express my most grateful thanks to Dr. S. Watari for his continous directions and constant encouragement throughout the investigation, and also to the members of my laboratory for their valuable advice. My thanks are also due to Dr. R. Aimi of the National Institute of Agricultural Science, Tokyo, for valuable materials.

\section{Summary}

The fundamental organization of the root tip of Oryza sativa L. was observed and discussed with special reference to the bevaviour of the initial cells and their derivatives in the promeristem.

Usually the promeristem has three sets of initial layers, i.e., the stelar, the cortexepidermal, and the root cap initials, thus the constructional type of promeristem being conformable to the most common pattern of grass roots.

In a few instances, however, the initials appear to be separated into four sets, that is, the stele, the cortex, the epidermis, and the root cap being derived from an 
independent group of initials respectively. Existence of two types of organization in one and the same species under a natural condition is very interesting, and probably has not been noticed by any workers.

It seems rather natural to consider that the initial cells maintain an ability of division. The cortex-epidermal initials which divide anticlinally, may occasionally divide also periclinally to form a four-layered initial zone. This fact seems to furnish an evidence of the latent ability of periclinal division of cortex-epidermal initials.

The cambial nature of endodermal cells is confirmed, that is, all of the cortical cells are the same in origin, though among the cells they differ in shape, size, dividing ability, as well as in the manner of division and elongation.

\section{References}

1) Haan, J. Van B. De, De Rijstplant 1. (1911). 2) Yung, C. T., Bot. Gaz. 99: 786 (1938). 3) Kaufman, P. B., Amer. J. Bot. 42: 649 (1955). 4) Heimsch, C., Amer. J. Bot. 38: 365 (1951). 5) Clowes, F. A. L., New Phytol. 53: 108 (1954). 6) Schüepp, O., Meristeme. In: K. Linsbauer, Handbuch der Pflanzenanatomie. Bd. 4. Lief. 16. (1926). 7) Clowes, F. A. L., New Phytol. 55: 29 (1956). 8) Jensen, W. A. and L. G. Kavaljian, Amer. J. Bot. 45: 365 (1958). 9) Pellegrini, O., N. S. Bull. dell' Ist. ed Orto Bot. dell' Univ. Napoli. 10: 187 (1957). 10) Juliano, J. B. and M. J. Aladama, Philippine Agriculturist 26: 1 (1937). 11) Guttenberg, H. von, Die physiologischen Scheiden. In: K. Linsbauer. Handbuch der Pflanzenanatomie. Bd. 5. Lief. 42. (1943). 12) Williams, B. C., Amer. J. Bot. 34: 455 (1947). 13) Boeke, J. E., Ann. Jard. Bot. Buitenzorg 50: 197 (1940).

\section{摘 要 \\ イネの根の頂端分裂組織の観察}

$$
\text { 島袋敬一 }
$$

イネの根端の組織の基本的構造，特に前分裂組織に挌ける始原細胞群の行動，ならびにそれに由来する 細胞の分裂方向について観察し論議した.

多くの場合，前分裂組織は縦断面で中心柱，皮層・表皮，拉よび根冠の 3 始原細胞群として区別でき， その構造はイネ科に普通にみられる型に属する.

しかし，少数例ではあるが，始原細胞群が 4 層一中心柱，皮層，表皮，根冠一飞わかたれ，特の特 の独立の始原細胞群飞由来していると考光られる場合がある． 1 個の種飞招いて，このよう飞根の前分裂 組織の構造が 2 型を示すことは興味ある問題であり, このことについては従来観察例が極めて少く, 殆ん ぞ論議されてない.

近来, 根の前分裂組織の細胞分裂の頻度, ならびそ始原細胞群の分裂能力等について種種論じられてい る. この研究での観察例は, 始原細胞群が分裂能力を持つことを示し, 特に皮層・表皮始原細胞群は縦断 面で anticlinal division を行らのが普通のようであるが，時に periclinal division の能力を発現するこ とによつて皮層・表皮の共通の始原細胞群が分離し，特の特の独立の起原上り生じ 4 層となつたと考光る のが至当であろう.

内皮の分裂能力についても観察した. 皮層のすべての細胞は分裂带の内皮細胞の periclinal division 飞 よつて形成される. しかし, 各部位, すなわち内皮, 薄膜柔細胞層の内, 中, 外層, 厚膜細胞呿よび外皮 の各細胞はその形, 大きさ, 内皮細胞より分離した後の分裂能力ならびに分裂, 伸長の方法が異なる. 

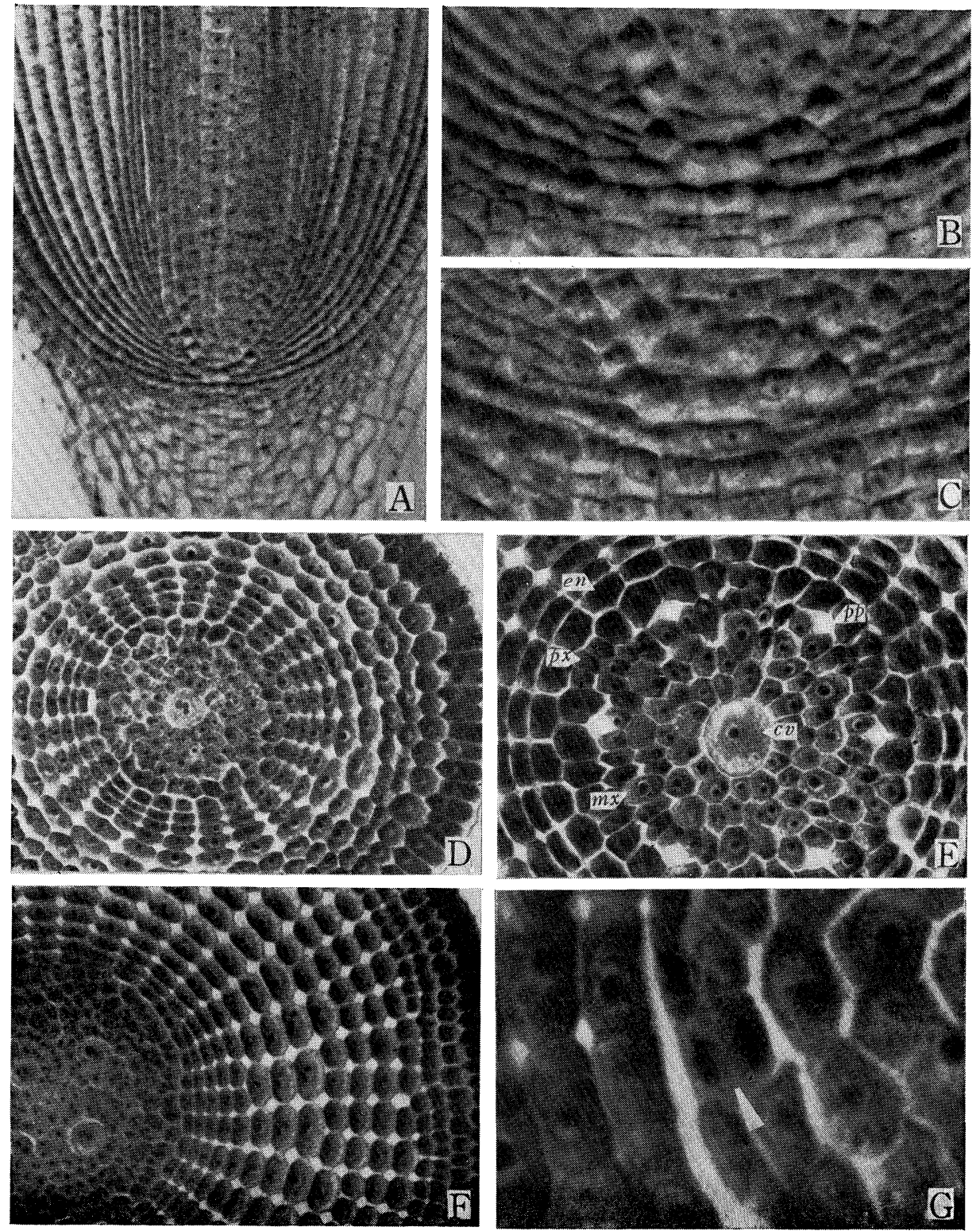

A-C. Median longitudinal sections of the root tip (cf. text figs. 1,2). A, ordinary feature of the root tip, $\times 240$; $\mathrm{B}$, a part of $\mathrm{A}$, under a higher magnification showing a part of promeristem with three-layered initial zone, $\times 800$; C, four-layered initial zone, $\times 800$.

D-G. Transverse sections. D, seminal root, showing the level $160 \mu$ from the tip, note the shape of the epidermal cells, the arrangement of the cortical cells, and staining reaction of the cortex, $\times 230$; E, level $280 \mu$ from the tip, under a higher magnification, showing an upper part of the same root as $\mathrm{D}, \times 430$, en endodermis, $p x$ protoxylem, $m x$ metaxylem, $p p$ ptotophloem, sieve-tube elements become clear and are mature in E, immature in $\mathrm{D}, c v$ central vessel; F, adventitious root, level $400 \mu$ from the tip, showing the four central vessels, and disturbance of radial rows of the cortical cells, $\times 240$; G, level $30 \mu$ from the tip, showing the periclinal division of the meristematic endodermal cell under a higher magnification, an arrow indicates the division, $\times 1,600$.

K. Shimabuku; Observation on the Apical Meristem of Rice Roots. 